\title{
FIELD STUDY PERFORMANCE OF TRACTION OF MASSEY FERGUSON TRACTOR
}

\author{
*Majed Salih Himoud \\ ABSTRACT
}

This research used (MF 285S) tractor for studying and evaluating its agricultural performance. The research used ploughing depthes of $(20,15,10) \mathrm{cm}$ to load its engine for forward speeds of $(1.8,2.23,3.88,4.68 \mathrm{~km} / \mathrm{h})$ in clay, sand and loam clay soils with moisture content of $20 \%$. The study showed that the value of highest tractive efficiency was (79\%), the wheel slippage (9\%) and the tractive coefficient was (44\%). The slip increased with increased tractive power for all engine speeds. Slip increased in 12\% 15\%. $22 \%$ and $26 \%$ in increasing of tractive power from 10 to $20 \mathrm{kN}$ for forward speeds $(1.8,2.23,3.88$, $4.68 \mathrm{~km} / \mathrm{h}$ ) respectively. The results also showed that range of optimum tractive was at power forward speeds $(1.8,2.23,3.88$ and $4.68 \mathrm{~km} / \mathrm{h})$ respectively.

\section{INTRODUCTION}

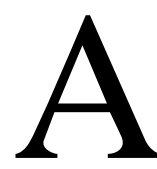
gricultural tractor is one of sources of mechanical power used in operating machines for performing agricultural processes. The tractor deals with many factors, among them are the weight on traction wheels, the type of soil, and the forward speed. Tractive efficiency, , tractive ability, slip and rolling resistance are considered the best indicators to evaluate tractive performance for agricultural tractors. The agricultural tractor must provide a high tractive power as in ploughing. This involves a high efficiency in transferring engine power to tractive effort._Jebur et al. (2013) indicates that the wheel slip increased with the increase in the traveling speed, while decreased by increasing the weight on the rear tractor wheels. Sahu and Raheman (2008) indicated in the study on matching and field performance, that wheel slip increased with the increase in draft and in implement system it is necessary to decide on matching implements with tractor. Issues concerning topsoil damage due to tyre slip should be taken into account and further investigated (Diserens and Battiato, 2012).

Dept. of Agricultural Machines and Equipment - Coll. of Agric. - Univ. of Basrah 
Taylor et al.(1991) and groups clarified that the range of slip is better when the tractive efficiency was optimized at (8.15\%) and out of this range the efficiency decreased in a remarked way. Aday (1997) clarified that the maximum tractive efficiency, lies in the range of tractive power $(10,20 \mathrm{kN})$ whereas the efficiency, out of this range decreased tractive power. Jebur et al. (2013) indicated that the traveling speed and the weight on the rear tractor wheels were the most important factors that affect the drawbar pull and the specific energy. Younis et al. (2010) indicated that the performance of drawbar test measured data of forward speed, and fuel consumption. The calculated data were the drawbar power, equivalent forward speed and drawbar pull. The maximum drawbar power was affected by drawbar pull as shows (62.31-62.58 kW) at highest forward speed of (3.7-6.72 km/h) respectively. Abraham (2014) indicated that the higher increasing in drawbar pull was measured during the tractor operation on the soil with higher moisture in comparison with the soil with lower moisture level. In case of soil moisture of $14 \%$ the increase in drawbar pull of tractor equipped with special wheels reached the value $17.2 \%$ compared with standard tires. Using the special wheels on the same field with higher level of soil moisture $(22 \%)$ the increase in drawbar pull reached $36.1 \%$ compared with standard tires. .Lyne et al .(1989) stated that the tractive efficiency can be optimized by selecting the appropriate dynamic load and inflation pressure. Sumer (2004) mentioned that the

tractive efficiency is the ability of engine, transmission and tractive systems.

This research aimed at evaluating field performance for a tractor Massey Ferguson through studying farm indicators. mainly tractive efficiency and rolling resistance.

\section{MATERIALS AND METHODS}

The research was conducted in a Basrah University (Garmat Ali). The experiment used engine speed $1500 \mathrm{rpm}$ and four forward speeds $(1.8,2.23,3.88,4.68 \mathrm{~km} / \mathrm{h})$ It also used with each forward speed three depths of plowing $(10,15,20 \mathrm{~cm})$..The soil type was silt clay, and the average soil moisture content during working time was $20 . \%$ 


\section{A-Description of agricultural equipment.}

\section{1.: Massey Ferguson $285 \mathrm{~S}$ tractor.}

- This tractor which is[ Two - wheel] drive. This tractor has a diesel engine - Perkins type -with four cylinders, four strskes, water cooled with brake power $56.6 \mathrm{~kW}(77 \mathrm{hp})$ at engine speed of $220 \mathrm{rmp}$. The effective weight on the forward and rear wheels were $12.63 \mathrm{kN} 17.37 \mathrm{kN}$ respectively The sizes of the rear and front tires are $18.4 / 15-30$ and 7.60-16 respectively.

\section{The John Deere tractor}

The John Deere tractor was used in order to hitch moldboard plow to raise and lower the plough with the MF285S tractor ( The tractor under the experiment ).

\section{Moldboard Plow}

This device was used in all experiments. Its width was $122 \mathrm{~cm}$ and not supplied by. The plow was used with depths of $(10,15,20 \mathrm{~cm})$ with the John deere tractor to load MF $285 \mathrm{~S}$ tractor.

\section{B-. Parameter measurements and determinations. 1-.The tractive force}

Tractive force measurement used (load cell). Measuring load cell was fixed behind MF joining head of John Deere tractor by data USB wire to laptop which lies inside the tractor cabin. The experiments were conducted by lowering the moldboard plow in the soil The operating depths and the forward speed of the tractor under test were Determined by putting the tractor in gear. The engine speed of the tractor was fixed at $1500 \mathrm{rpm}$. The tractor was then left to approach the maximum forward speed then the readings were recorded from the measuring load cell along a distance of $20 \mathrm{~m}$. Each run was repeated three times.

\section{2-The theoretical velocity}

The theoretical velocity of the tractor was calculated for each forward speed
by:

$$
V t=\frac{D}{t}
$$


Where Vt is the theoretical velocity of the tested tractor $(\mathrm{m} / \mathrm{sec})$.

$\mathrm{D}$ is the distance traveled by the tested tractor $(20 \mathrm{~m})$ on hard surface.

$\mathrm{t}$ is the time taken by the tractor to move a distance of $20 \mathrm{~m}$ (sec).

\section{3- The actual forward velocity}

The actual forward velocity of the tractor was calculated as follows:

$$
V a=\frac{D}{t 1}
$$

Where: $\mathrm{Va}$ is the actual forward velocity of the tested tractor $(\mathrm{m} / \mathrm{sec})$.

$\mathrm{t}_{1}$ is the time taken to move distance of $20 \mathrm{~m}$ in the field $(\mathrm{sec})$.

\section{4- The rolling resistance}

The rolling resistance was measured for the MF205S tractor in the field for engine speed of $1500 \mathrm{rpm}$ and for four forward speeds $(1.8,2.23,3.88$ and $4.68 \mathrm{~km} / \mathrm{h}$ ). The tested

tractor was pulled by another tractor on the soil surface of the field of the experiments. The rolling resistance was measured directly from load cell for the tractor force between two tractors. The rolling resistance was measured for all the forward speeds used in the research. Each run was repeated three times, and taking the averages.

\section{5- Wheel slip (S):}

The traction wheels slip (\%) is calculated as follows:

Where

$$
S=\frac{V 1-V 2}{V 1} \times 100
$$

S : wheel slip, \%

V1: traveling speed without load $\mathrm{km} / \mathrm{h}$.

V2: traveling speed with load $\mathrm{km} / \mathrm{h}$.

\section{6- Drawbar power (Pdb):}

Drawbar Power $(\mathrm{kW})=$ Net drawbar pull $(\mathrm{kN}) \times$ Actual forward speed $(\mathrm{km} / \mathrm{h}) / 3.6$

\section{7- Tractive efficiency (TE):}

The traction efficiency of the tractor under test was calculated as follows:

$$
T E=\frac{F(1-S)}{H} \times 100
$$


Where:

TE : tractive efficiency $\%$

$\mathrm{S}=$ the traction wheels slip.

$\mathrm{H}=$ the thrust force $(\mathrm{kN})$

$\mathrm{F}=$ the drawbar pull $(\mathrm{kN})$

\section{8-Draft power}

The draft power was calculated as follows:

$$
\mathrm{PF}=\mathrm{F}^{*} \mathrm{Va}
$$

Where $\mathrm{PF}=$ the draft power $(\mathrm{kW})$.

\section{9- Available power}

The power available at the traction wheels is calculated as follows:

$$
\mathrm{Pd}=\mathrm{H}^{*} \mathrm{Vt}
$$

Where $\mathrm{Pd}=$ the power available at the traction wheels $(\mathrm{kW})$.

$\mathrm{Vt}=$ the theoretical forward speed of the tractor $(\mathrm{m} / \mathrm{sec})$.

$\mathrm{H}=$ the thrust force $(\mathrm{kN})$

\section{0-Thrust force}

The tractor thrust can be calculated as follows:

$$
\begin{gathered}
\mathrm{H}=\mathrm{F}+\mathrm{R} \\
\mathrm{R}=\text { rolling resistance }(\mathrm{kN})
\end{gathered}
$$

\section{1- Tractive coefficients}

The traction coefficient was calculated as follows:

$$
C T=\frac{F}{Z r}
$$

Where: $\mathrm{CT}=$ traction coefficient of the tractor

$\mathrm{Zr}=$ the normal force of the tractor acting on the rear wheels $(\mathrm{kN})$

\section{RESULTS AND DISCUSSION}

\section{1-The relationship between tractive efficiency and tractive coefficient} with slip. The tractive efficiency increased with increasing of slip reaching to maximum value of 0.79 . Then decreased and the cause of increasing in the beginning belongs to increasing drawbar pull which is bigger than increasing in slip power. This means that the amount of tractive ability is bigger than losing power. The results showed that 
maximum tractive efficiency was with slip of 0.09. Weight on traction wheels, therefore increases tractive coefficient up to slip of 0.44 the cause of increasing in tractive coefficient in the beginning is related to the high increasing of the drawbar pull with slip. Meanwhile, the soil is destroyed by increasing by drawbar pull and the slip increased in a clear way.

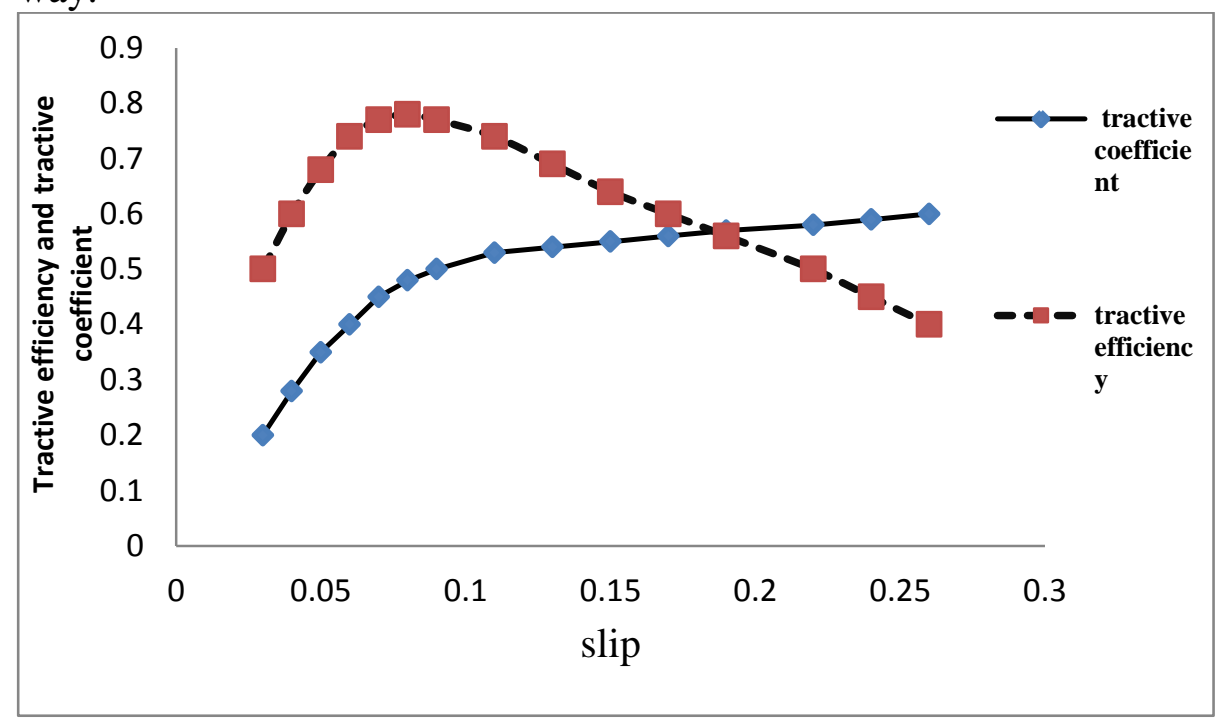

Fig.1: The relationship between tractive efficiency and tractive coefficient with slip.

\section{2- Relationship between tractive power for forward speed with slip}

Fig(2) shows the relationship between tractive pull for four forward speeds, for tractor $((1.8,2.23,3.88,4.68 \mathrm{~km} / \mathrm{h})$. Increasing of tractive pull increased slip for four forwards speeds. This is related to the increasing of speed. and tractive power which related to the increasing of pull power, which accomplished by increasing of soil which increases slippage. The results show the differences in slippage between the test forward speeds in lowering tractive power.

\section{3-The relationship between tractive efficiency and drawbar pull for forward speeds.}

Figure (3) shows the relationship between tractive efficiency and tractive power for four forward speeds for atractor $(1.8,2.23,3.88,4.68 \mathrm{~km} / \mathrm{h})$. 


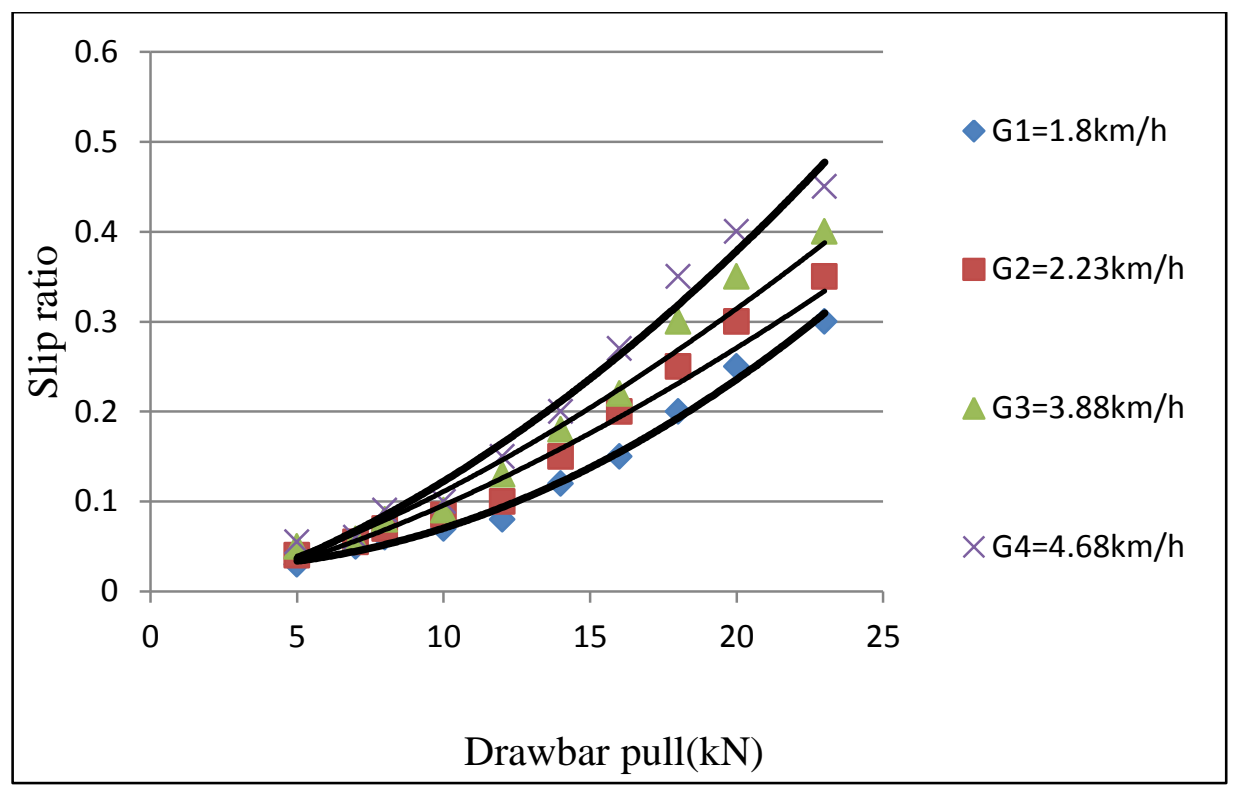

Fig.2: Relationship between drawbar pull for forward speed with slip ratio

The increasing of tractive efficiency with increasing of tractive pull reaches the maximum value of 0.74 in tractive pull of (12) $\mathrm{kN}$, but the difference in tractive efficiency for forward speeds increased after tractive pull (16) $\mathrm{kN}$ where the maximum efficiency decreased for the fourth, third, second and first speeds for tractive pull $(16,18,20,22) \mathrm{kN}$ respectively. This is because slippage increased with the forward speeds in order to overcome soil resistance to get a big pull power and also to overcome shappage which increases with increasing forward speed and the increasing losses by wheels. Therefore tractive pull in maximum efficiency which decreased by increasing forward speed. The ranges for speed $(1.8,2.23,3.88,4.68 \mathrm{~km} / \mathrm{h})$ it show that increasing forward speed leads to decreasing of tractive power and this means losing ability in wheels as a result of slippage. However the increasing of forward speeds leads to increasing the productivity of tractor and therefore, you can use forward speeds for tractor on a condition that the tractive power lies in recommended range. 


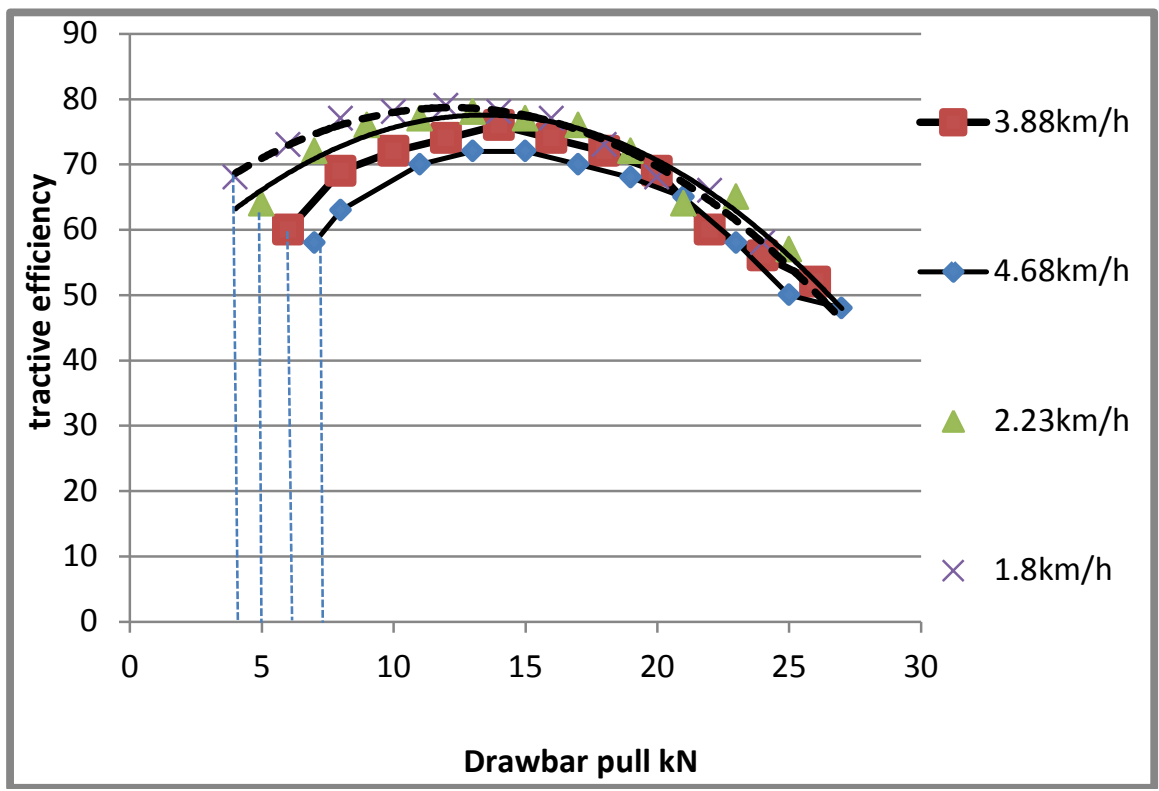

Fig. 3: Relation between tractive efficiency and drawbar pull for forward speeds

\section{CONCLUSION}

1-The greatest tractive efficiency was (79\%) with wheel slippage of $(9 \%)$ and tractive coefficient (44\%).

2-The wheel slip increased with the increase in the traveling speed.

3-The drawbar pull increased with the increase in the traveling speed.

\section{REFERENCES}

Abraham(2014) Increase in tractor drawbar pull using special wheels, Agronomy Research 12(1),7-16.

Aday, S.H. (1997) Field studying of two wheels drive tractor performance when operating with passive implements, Mesopotamia J.Agric.,29(22).

Diserens, E., Battiato, A. 2012. Traction force in arable farming: Agron and env aspects after field-data acquisition and modelling. In:I.1 Conf. Ag. Eng CIGR-Ag.Eng, June 8-12, Valencia, Spain 
Dwyer, M.J.(1984). The tractive performance of wheeled vehicles.J. Terramechanics, 21(1): 19-34.

Dwyer, M.J.(1978). Maximum agricultural tractor performance by matching weight, tyre size and speed to the power available. Proc. Of 6th iInt. Conf. of Int. Soc, for Terrain Vehicle system. Vienna, Austria

Jebur H.A., M. M. Mostafa; E.A. El-Sahhar; M.A. El-Attar and M. A.Elnono (2013). Performance Evaluation of farm tractor using variable weights on rear wheels during ploughing and sowing operation. Misr J. Ag. Eng., 30 (3): 645 - 660

Jenane, C.; L.L. Bashford and G. Monroe (1996).Reduction of fuel consumption through improved tractive performance. J. Agric. Engng. Res., 64: 131-138.

Lyne,P.W.L and E.C.But.(1989). Real-time optimization of tractive efficiency .Trans of the ASAE 32(2):431-43

Sahu R.K., and H. Raheman 2008. A decision support system on matching and field performance prediction of tractor-implement system. Computers and Electronics in Ag 60: 76-86.

Sumer,S.K.(2004).Effect of different tire configurations on tractor performance. Turk J AGRIC.,29(2005):461-468.

Taylor, R;Schroch,M.and Kelly, W.(1991). Getting the tnost form your tractor farm machinery and equipment .Coop Extension Service, Kansas State U, Manhttan, MF-588.

Wang ,G; Kushwaha,R.L.and Zoerb,G.C; (1989).Tractive performance of a model 4WD tractor .Can: Agric.Eng 31,125-129

Younis S.M., R.E. EL-Said, F.B. Ahmed., and M.E. Islam, 2010. Development a local system for measuring tractors performance. Misr.J.Agric. Eng., 27(1):34-53. 


\section{الملخص العربى \\ دراسة حقلية لاداء سحب الجرار ماسي فيرجسن \\ *ماجـد صالـح حمود}

استخدم في هذا البحث جرار ماسي فيرجسن (MF285S) لار اسة وتقييم أدائه الحقلي حيث تم

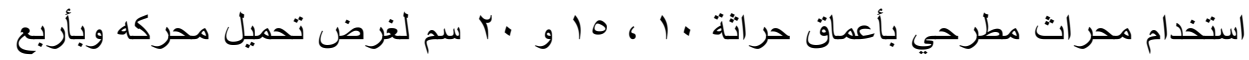

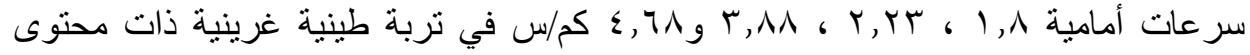

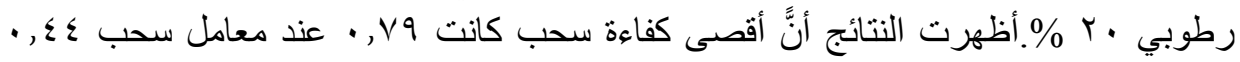

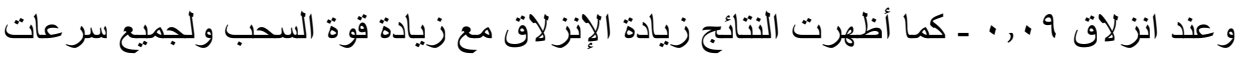

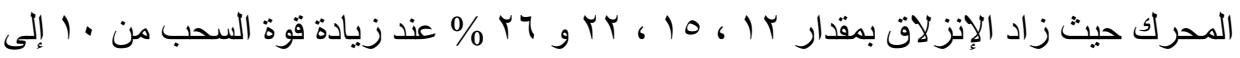

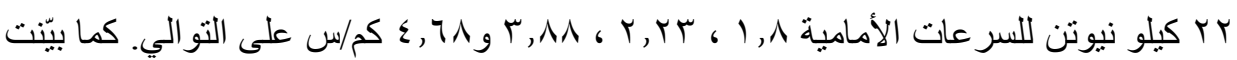
النتائج أن هنالك مديات من قوة السحب يعمل ضمنها الجرار عند كفاءة السحب القصوى. ورهذ

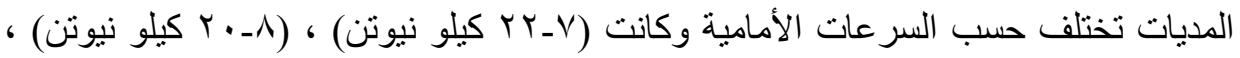

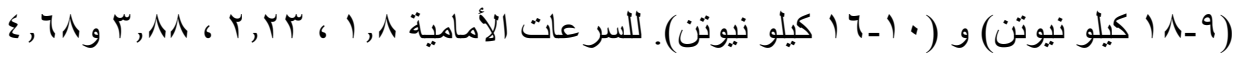
كم/س على التو الي. 